\title{
PENERAPAN MODEL PEMBELAJARAN KOOPERATIF BERBANTUAN APPLET GEOGEBRA UNTUK MENINGKATKAN PEMAHAMAN KONSEP DAN PRESTASI BELAJAR TRIGONOMETRI
}

\author{
Ika Wulandari \\ SMK N 2 Wonosari \\ E-mail: ariensuharyono@yahoo.co.id
}

\begin{abstract}
Abstrak
Penelitian ini adalah penelitian tindakan kelas. Tujuan penelitian ini untuk mengetahui apakah pembelajaran trigonometri model kooperatif dengan menggunakan eksplorasi applet GeoGebra dapat meningkatkan pemahaman konsep dan meningkatkan prestasi belajar siswa. Subjek dalam penelitian ini adalah siswa kelas XI Mesin SMKN 2 Wonosari sebanyak 32 siswa. Data pemahaman konsep dan hasil belajar diambil dengan tes dan wawancara. Data hasil tes dan wawancara diolah serta disajikan secara deskriptif. Proses penelitian dilaksanakan dalam dua siklus. Setiap siklus mencakup empat tahapan, yaitu tahap perencanaan, tahap tindakan, tahap observasi, dan tahap refleksi. Indikator kinerja dalam penelitian ini adalah: (1) Adanya peningkatan pemahaman konsep, (2) Adanya peningkatan prestasi belajar yang ditunjukkan dengan rata-rata nilai tes yaitu sekurang-kurangnya $80 \%$ siswa dapat memperoleh nilai di atas batas ketuntasan minimal (78). Hasil penelitian menunjukkan, setelah melewati proses pembelajaran 2 siklus yang didalaminya dilaksanakan refleksi, terlihat adanya peningkatan persentase ketuntasan hasil belajar. Terlihat dari proses awal sampai siklus terakhir, kedua indikator kinerja tercapai. Jadi kesimpulan dalam penelitian ini adalah pembelajaran trigonometri dengan model kooperatif berbantuan applet GeoGebra tersebut dapat meningkatkan prestasi belajar siswa Kelas XI Mesin SMKN 2 Wonosari Kabupaten Gunungkidul Tahun Pelajaran 2014/2015.
\end{abstract}

Kata kunci: eksplorasi GeoGebra, prestasi siswa, trigonometri.

\section{Latar Belakang}

Kurikulum 2013 mengedepankan pola pikir pembelajaran yang memfasilitasi agar siswa aktif, interaktif, dan kritis dalam memahami konsep matematika. Pola pikir tersebut diimplementasikan dalam proses pembelajaran sesuai standar proses untuk mencapai tujuan pembelajaran. Agar tujuan dalam proses pembelajaran dapat tercapai, pembelajaran harus bermakna bagi siswa. Pembelajaran bermakna adalah pembelajaran yang lebih mengutamakan pengertian daripada hafalan. Pembelajaran yang bermakna tidak mudah dilupakan oleh siswa serta dapat dijadikan sebagai modal untuk membangun konsep selanjutnya atau untuk menghadapi masalah dalam dunia nyata.

Pembelajaran yang bermakna harus mengacu pada standar proses, yaitu dengan menekankan pada penalaran (reasoning) dan pengembangan pemahaman (sense making). Artinya agar proses belajar dapat terlaksana sesuai standar proses, harus didukung dengan sarana, prasarana, dan media pembelajaran. Proses belajar yang kurang bermakna dengan media sumber belajar yang hanya menekankan pada ketrampilan prosedural saja, akan mudah dilupakan siswa dan berpotensi menimbulkan miskonsepsi serta kesulitan belajar trigonometri.

Berdasarkan hasil observasi dan pre-tes diketahui bahwa siswa mengalami kesulitan belajar trigonometri. Kesulitan belajar yang dialami siswa terdeteksi dengan adanya kesalahan konsep, prinsip, dan prosedur dalam menyelesaikan soal-soal tes trigonometri. Temuan tersebut akan menghambat proses pembelajaran berikutnya yaitu aplikasi trigonometri. Oleh karena itu sebelum mempelajari aplikasi trigonometri, kesulitan siswa dalam pemahaman konsep, prinsip, dan 
prosedur trigonometri harus diperbaiki terlebih dahulu.

Berdasarkan penelitian dalam pembelajaran oleh Weber (2005), Challenger (2009), dan Orhun (2001) terungkap bahwa siswa mengembangkan pemahaman fungsi trigonometri secara terpisah-pisah (tidak berhubungan antar konteks yang dipelajari). Hasil riset tersebut juga menunjukkan bahwa siswa mengalami kesulitan dan miskonsepsi pada subjek trigonometri. Dalam penelitiannya, Demir (2012:1) menyatakan bahwa tidak mudah bagi siswa untuk mengembangkan pemahaman yang menghubungkan antar konteks dalam trigonometri, dan cara mengajar konvensional (ceramah/hafalan) tidak dapat memperbaiki kesulitan belajar siswa.

Terkait dengan kesulitan belajar dan pencapaian hasil belajar siswa, Challenger (2009: 55) menyampaikan bahwa apapun hasil pembelajaran yang ditampilkan oleh siswa tidak lepas dari lingkungan belajarnya yang meliputi metode mengajar, kegiatan siswa, kurikulum, dan media pembelajaran. Kultur, et al. (2011: 123) menyarankan beberapa cara untuk mengatasi miskonsepsi siswa dan guru, serta untuk meningkatkan pembelajaran yang bermakna antara lain dengan: memfasilitasi pembelajaran konsep secara mendalam, menghubungkan pengetahuan prasyarat dengan pengetahuan yang baru, serta menggunakan media kognitif untuk mengonstruksi konsep yang abstrak.

Joolingen (1999: 389) dalam jurnalnya mengutip sebuah pandangan tentang cognitive tools dari buku yang diedit oleh Lajoie and Derry, bahwa komputer dapat mendukung pembelajaran secara eksplisit atau dapat mewakili proses kognitif. Joolingen menjabarkan tentang media kognitif tersebut secara umum dapat didefinisikan sebagai instrumen yang didesain untuk mendukung proses kognitif. Joolingen memberikan contoh alat kognitif misalnya software untuk memvisualisasikan proses dan domain sebuah grafik, animasi, dan lain-lain, seperti alat yang dapat membantu menyusun struktur proses berpikir. Media atau alat-alat bantu kognitif tersebut berfungsi sebagai pendukung untuk mencapai tujuan dalam proses pembelajaran.

Beberapa penelitian tentang penggunaan program komputer untuk mengatasi miskonsepsi dan kesulitan belajar trigonometri telah dilakukan. Blackett \& Tall (1991), melakukan penelitian untuk mengetahui efek pada pembelajaran menggunakan bantuan software yang memungkinkan siswa untuk mengeksplorasi hubungan antara representasi numerik dan visual dari perbandingan trigonometri dalam segitiga siku-siku. Hasilnya penggunaan software tersebut memberikan efek positif dalam belajar trigonometri. Kesimpulan yang sama juga ditemukan dalam penelitian yang dilakukan oleh Zengin, et al. (2012: 187) bahwa pengintegrasian teknologi memberikan dampak positif dalam meningkatkan pembelajaran dan pemahaman. Sedangkan Lotfi \& Mafi (2012) memproduksi software COTACSI, dalam penelitian eksperimennya ditemukan bahwa penggunaan software COTACSI memberikan efek positif pada pembelajaran trigonometri.

Beberapa penelitian tersebut menyimpulkan bahwa dengan menggunakan multimedia dapat membantu proses pembelajaran menjadi lebih efektif, lebih menarik, lebih memotivasi siswa, serta dapat memberikan pengalaman yang berkualitas bagi siswa. Pembelajaran trigonometri berbantuan komputer memberikan perubahan yang besar yaitu kesempatan untuk membantu siswa terlibat dengan konsep trigonometri serta dapat berinteraksi langsung dengan ide-ide trigonometri melalui media teknologi dalam cara yang lebih aktif. Oleh karena itu, untuk memperbaiki kesulitan belajar trigonometri tersebut, penelitian tindakan kelas ini menggunakan strategi pembelajaran kooperatif yang mengintegrasikan teknologi dalam pembelajaran konsep. Teknologi yang dimaksud adalah eksplorasi applet GeoGebra yang dapat diunduh dengan gratis dari GeoGebratube. Semua applet GeoGebra yang digunakan dalam penelitian tindakan kelas ini, bukan di desain oleh peneliti sendiri, melainkan mengunduh secara gratis dari http://www. geogebratube.org/.

Penelitian ini dilaksanakan dalam dua siklus dengan menekankan pada proses diskusi 
kelompok dan eksplorasi applet GeoGebra. Tujuan tindakan tersebut untuk mengetahui proses dan peningkatan pemahaman konsep, serta peningkatan prestasi belajar trigonometri. Dengan adanya proses pemahaman konsep diharapkan kesulitan belajar trigonometri berupa kesalahan konsep, prinsip, dan prosedur dapat diatasi, serta mengakibatkan prestasi belajar siswa meningkat.

\section{Metode Penelitian}

Penelitian ini menggunakan metode penelitian tindakan kelas. Subyek penelitian ialah siswa yang mendapat pembelajaran trigonometri pada semester gasal yakni siswa kelas XI Mesin SMKN 2 Wonosari sebanyak 32 siswa. Data kualitatif diambil dengan lembar pengamatan dan wawancara, sedangkan data kuantitatif diambil dengan tes. Data yang diperoleh diolah dengan menggunakan analisis deskriptif.

Proses penelitian dilaksanakan dalam dua siklus. Rencana pembelajaran untuk siklus 2 direvisi berdasar hasil refleksi siklus sebelumnya. Setiap siklus mencakup empat tahapan, yaitu tahap perencanaan, tahap tindakan, tahap observasi, dan tahap refleksi. Indikator kinerja dalam penelitian ini adalah: (1) Adanya peningkatan pemahaman konsep, (2) Adanya peningkatan prestasi belajar yang ditunjukkan dengan rata-rata nilai tes yaitu sekurang-kurangnya $80 \%$ siswa dapat memperoleh nilai di atas batas ketuntasan minimal (78).

\section{Hasil Penelitian Dan Pembahasan}

Berdasarkan hasil observasi, pre-tes, dan wawancara diketahui hasil pencapaian tes prestasi belajar trigonometri ditemukan belum mencapai batas ketuntasan minimal seperti tertera pada Tabel 1.

Tabel 1. Rekap Data Awal

\begin{tabular}{lc}
\hline \multicolumn{1}{c}{ Indikator } & Data Awal \\
\hline Nilai rata-rata & 21 \\
\hline Nilai tertinggi & 55 \\
\hline Nilai terendah & 10 \\
\hline Belum tuntas $(<78)$ & 32 \\
\hline Persentase ketuntasan & 0 \\
\hline
\end{tabular}

Soal Pre Tes yang digunakan dirancang sekaligus sebagai tes diagnostic kesulitan belajar siswa pada materi pra syarat untuk menguasai trigonometri. Tes diagnostik digunakan untuk menggali informasi tentang kesulitan belajar trigonometri yang dialami siswa. Berikut ini cuplikan wawancara dengan siswa R1 yang menunjukkan bahwa siswa tersebut memahami konsep sudut sebagai hasil dari sebuah pengukuran sudut. Cuplikan transkrip wawancara seperti di bawah ini:

$\mathrm{P} \quad$ : Pengertian $1^{\circ}$ itu yang bagaimana? $1^{\circ}$ itu seperti apa? $1^{\circ}$ itu yang bagaimana kalo dalam satu lingkaran penuh? (jeda) Oke, bisa digambarkan $1^{\circ}$ itu seperti apa?

$$
\begin{array}{lll}
\mathrm{R} 1 & : & 1^{\circ} ? \\
\mathrm{P} & : & \text { Iya. (jeda) } \\
\mathrm{R} 1 \quad: & \text { Misalnya seperti ini, bu? (meng- } \\
& \quad \text { gambar sudut) } \\
\mathrm{P} \quad: & \text { Iya. Itu } 1^{\circ} \text { ? }
\end{array}
$$

R1 : Pokoknya ya derajat seperti ini, bu.

Hasil tes dan wawancara mengungkap bahwa siswa mengenal konsep derajat pada lingkaran dengan berapapun ukuran jari-jarinya. Siswa tidak memahami konsep derajat dalam sebuah lingkaran satuan. Sedangkan sebagian besar siswa memahami konsep sudut sebagai hasil dari sebuah pengukuran sudut. Sejalan dengan penelitian Thompson (2008: 34) dan Tuna (2013:4), terungkap bahwa siswa tidak jelas dalam menangkap konsep sudut, sehingga memahaminya sebagai hasil pengukuran sudut. Artinya menurut Thompson, hal ini bukan hanya terbentuk dari hasil pembelajaran yang salah konsep, melainkan juga disebabkan oleh penyajian pembelajaran sudut dalam buku-buku pelajaran dan di kelas yang menyajikan gambar sudut dengan menunjuk pada ukurannya bukan pada proses terbentuknya.

Berdasarkan hasil tes dan wawancara secara mendalam diketahui bahwa siswa mengalami kesulitan belajar trigonometri meliputi: konsep derajat, konsep radian, menentukan nilai fungsi trigonometri dalam radian, menentukan nilai fungsi trigonometri dalam derajat, menentukan nilai fungsi trigonometri dalam pi radian, membedakan fungsi/bukan fungsi, mengenali 
domain dan range sebagai himpunan bilangan riil, mengidentifikasi domain, mengidentifikasi range, dan mengidentifikasi periode fungsi trigonometri.

Oleh karena itu peneliti mendesain pembelajaran kooperatif berbantuan teknologi yaitu dengan memberi kesempatan siswa berdiskusi dengan kelompok yang terdiri dari 2 orang dan mengeksplorasi applet GeoGebra untuk menyelesaikan masalah dalam lembar kegiatan siswa. Pembelajaran dimulai dengan pemaparan apersepsi dan eksplorasi GeoGebra menggunakan LCD oleh guru. Kemudian siswa secara berkelompok mengeksplorasi geogebra menggunakan laptop siswa yang sudah terinstal GeoGebra.

Desain tersebut diharapkan mampu mengatasi kesulitan belajar siswa. Desain pembelajaran ini dituangkan dalam rencana yang berisi langkahlangkah pelaksanaan kegiatan pembelajaran, dilengkapi dengan lembar kegiatan siswa yang berisi format laporan hasil eksplorasi. Peneliti juga mempersiapkan Instrumen penelitian lainnya berupa lembar observasi, pedoman wawancara, lembar validasi instrumen penelitian, kisi-kisi, soal tes prestasi, dan pembahasan, serta pedoman wawancara.

Pada tahapan pelaksanaan Siklus I, peneliti dibantu rekan observer melaksanakan proses pembelajaran sesuai dengan perencanaan yang dibuat yaitu satu siklus terdapat 4 tatap muka dan 1 pertemuan untuk tes prestasi. Pembelajaran diawali dengan pembagian kelompok dan pemberian tugas dalam Lembar Kegiatan Siswa. Tugasnya adalah mengeksplorasi applet GeoGebra kemudian menulisnya dalam bentuk laporan, mempresentasikan, dan mendiskusikan secara klasikal. Kesulitan dalam memahami konsep radian dan derajat, diperbaiki dengan mengeksplorasi applet GeoGebra seperti tampilan pada Gambar 1 berikut ini.

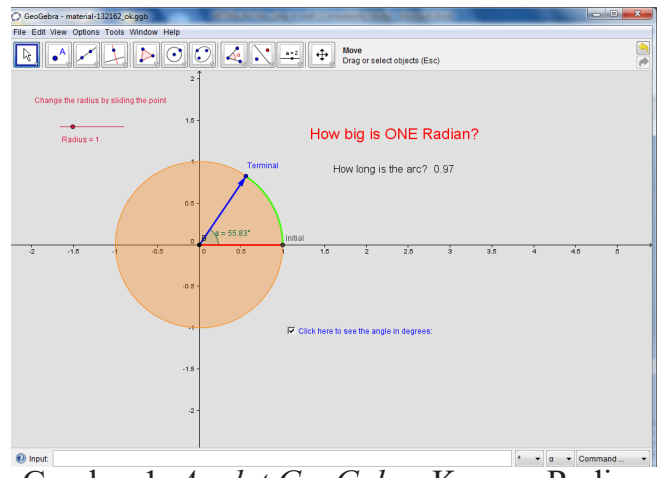

Gambar 1. Applet GeoGebra Konsep Radian dan Derajat

Hasil pengamatan menunjukkan bahwa mulanya siswa terlihat lambat dan kurang kondusif dalam mengerjakan tugas yang diberikan, siswa kesulitan memahami cara kerja eksplorasi applet GeoGebra karena belum pernah menggunakan applet GeoGebra. Kemudian suasana menjadi kondusif setelah guru memberi petunjuk mengoperasikan dan mengeksplorasi applet GeoGebra. Hasil pengamatan menunjukkan bahwa siswa menjadi sibuk dan aktif bereksplorasi. Pada sesi presentasi terlihat beberapa kesalahan konsep yang terjadi pada siswa menjadi perdebatan hangat antar kelompok. Dengan mengeksplorasi aplet tersebut, siswa dapat membandingkan perbedaan nilai besar sudut dalam radian dan derajat. Siswa menuliskan hasilnya dalam tabel, kemudian membandingkan, menganalisisnya, dan membuat simpulan tentang definisi/ pengertian konsep derajat dan radian dengan bahasa siswa sendiri serta menentukan nilai konversinya.

Selain itu beberapa siswa masih belum paham tentang penggunaan konsep radian. Menurut penuturan siswa, hal ini dikarenakan siswa sangat jarang bahkan ada yang merasa tidak pernah mengerjakan persoalan trigonometri dalam sistem radian. Pada umumnya soal-soal trigonometri dari guru dan buku teks disajikan dalam sistem derajat, dan terbatas pada sudutsudut istimewa saja. Kesalahan prosedur juga terjadi saat siswa diminta menentukan nilai cosines dengan menjawab sebagai berikut.

Kesalahan prosedur terungkap saat siswa menulisnya dipapan tulis dengan tidak konsisten, sehingga hasil akhirnya salah. 
Siswa menuturkan bahwa ia hanya menghafal langkah-langkah mengerjakan soal tipe ini. Siswa juga mengaku kesulitan menghafalkan rumus-rumus konversi di berbagai kuadran karena sangat banyak dan sulit bagi siswa.

Kesulitan dalam menentukan nilai fungsi trigonometri di berbagai kuadran, diperbaiki dengan mengeksplorasi applet GeoGebra tampak pada cuplikan tampilan applet GeoGebra pada Gambar 2 berikut ini.

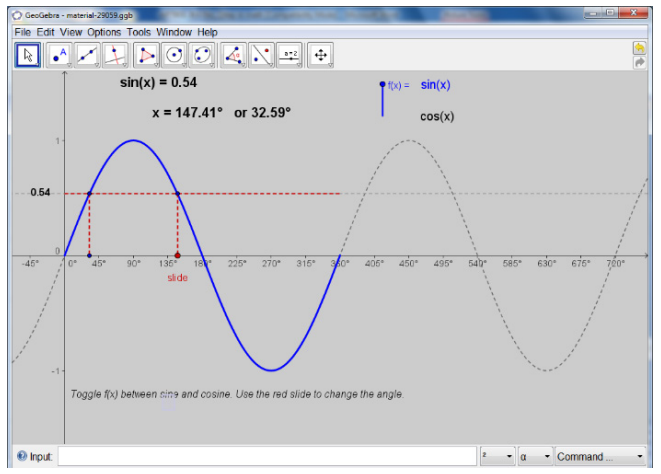

Gambar 2. Applet GeoGebra Nilai Fungsi Trigonometri

Eksplorasi pada applet Nilai Fungsi Trigonometri, melatih siswa mengamati nilai fungsi trigonometri dalam berbagai kuadran. Siswa mendata hasil eksplorasi dalam tabel, kemudian mengamati perubahan dan karakteristiknya di setiap kuadran, serta menarik simpulan dari fakta yang ditemukan.

Kesulitan dalam mengenali property grafik fungsi trigonometri, diperbaiki dengan mengeksplorasi applet GeoGebra tampak pada cuplikan tampilan applet GeoGebra pada Gambar 3 berikut ini.

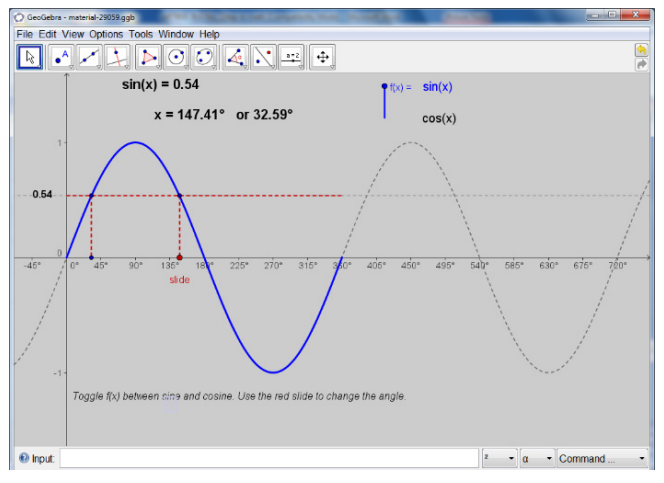

Gambar 3. Applet GeoGebra Property Grafik Fungsi Trigonometri
Siswa diminta mengamati perbedaan grafik yang terbentuk, menentukan representasi numerik, verbal, serta simbolis/ aljabarnya. Siswa mengenali karakteristik grafik berupa domain, kodomain, range, amplitudo, titik maksimum dan minimum, dan lain sebagainya.

Pada sesi kegiatan penutup, siswa dengan bimbingan guru mengadakan refleksi, penarikan simpulan (pelurusan kesalahan konsep) hasil diskusi dan penguatan konsep. Kegiatan tersebut dilaksanakan dalam 4 kali tatap muka. Kemudian pada tatap muka ke-5 diadakan tes siklus I yang terdiri dari 10 butir soal terkait konsep derajat dan radian, menentukan nilai fungsi trigonometri, mengidentifikasi properti grafik fungsi trigonometri, dengan hasil tersaji dalam Tabel 2.

Terdapat peningkatan untuk pencapaian nilai terendah, tertinggi, rata-rata kelas, dan banyaknya siswa yang tuntas atau mencapai Kriteria Ketuntasan Minimal $(\mathrm{KKM}=78)$. Namun demikian pencapaian nilai terendah dan rata-rata kelas masih jauh dari target. Hanya 28\% siswa saja yang mendapatkan skor tuntas. Peningkatan dari kondisi awal sebelum tindakan hingga tes siklus I, dapat dilihat dalam Gambar 4.

Diperlukan usaha yang lebih serius untuk meningkatkan skor ketuntasan pada siklus berikutnya. Pada Siklus ini dilakukan refleksi. Pada tugas eksplorasi siswa diminta tetap mengerjakan dan berdiskusi kelompok. Pada presentasi hasil eksplorasi, siswa juga diberi kesempatan berani mengemukakan pendapat, diupayakan terjadi diskusi sehingga terungkap kesalahan-kesalahan konsep yang terjadi pada semua siswa.

Peningkatan pada siklus I yang masih rendah sebagai dampak kurang optimalnya kegiatan presentasi dan siswa belum terbiasa dalam menganalisis hasil eksplorasi applet GeoGebra. Akibat kurang maksimalnya kegiatan presentasi dan diskusi sehingga kesalahan-kesalahan konsep yang dialami siswa belum semuanya terungkap. Sehingga saat mengerjakan tes, masih banyak siswa yang mengalami kesalahan konsep dan prosedur. 
Tabel 2. Deskripsi Hasil Tes Siklus I

\begin{tabular}{lllll}
\hline No. & Indikator & $\begin{array}{c}\text { Kondisi } \\
\text { Awal }\end{array}$ & $\begin{array}{c}\text { Siklus } \\
\text { I }\end{array}$ & Keterangan \\
\hline 1 & $\begin{array}{l}\text { Nilai } \\
\text { terendah }\end{array}$ & 10 & 35 & Makin baik \\
\hline 2 & $\begin{array}{l}\text { Nilai } \\
\text { tertinggi }\end{array}$ & 55 & 90 & Makin baik \\
\hline 3 & Rata-rata & 21 & 67 & Makin baik \\
\hline 4 & Ketuntasan & $0 \%$ & $28 \%$ & Makin baik \\
\hline
\end{tabular}

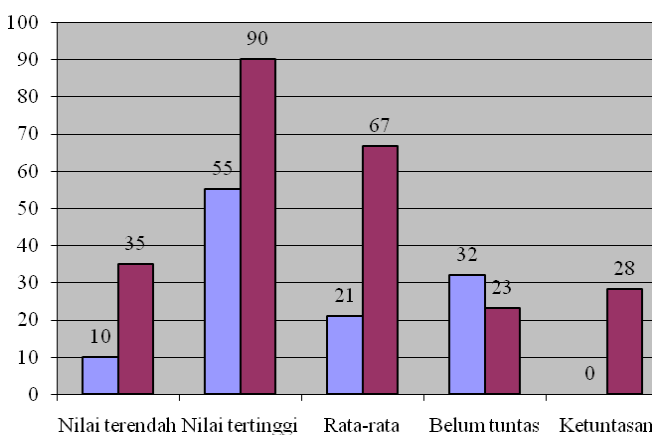

Gambar 4. Grafik Hasil Pre Tes dan Siklus I

Pada tahapan pelaksanaan Siklus II, peneliti dibantu rekan observer melaksanakan proses pembelajaran sesuai dengan perencanaan yang dibuat yaitu satu siklus terdapat 5 tatap muka dan 1 pertemuan untuk tes prestasi. Pembelajaran dimulai dengan pemberian tugas kelompok dalam lembar kegiatan siswa (LKS). Tugasnya adalah mengeksplorasi applet GeoGebra kemudian melaporkan hasil eksplorasi dalam bentuk laporan kegiatan siswa, mempresentasikan, dan mendiskusikan secara klasikal.

Kesulitan dalam mengonversi derajat dan radian, diperbaiki dengan mengeksplorasi applet GeoGebra seperti tampilan pada Gambar 5 berikut ini.

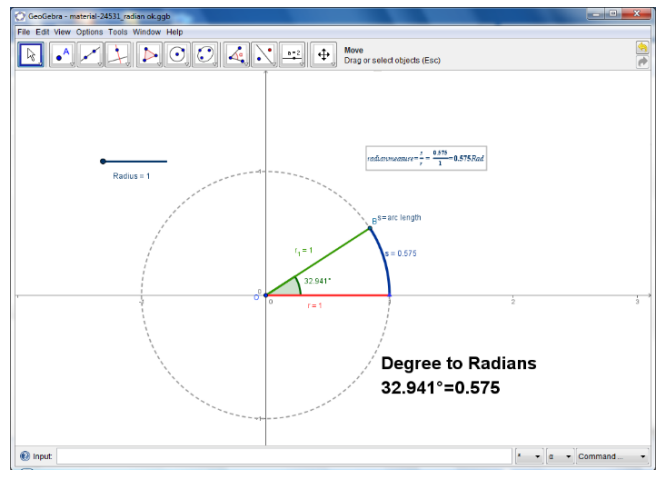

Gambar 5. Applet GeoGebra Konversi Radian dan Derajat

Pada siklus I, hal ini sudah dipelajari, namun karena hasilnya belum baik, maka applet ini digunakan untuk memperjelas pemahaman sebelumnya. Pada applet ini sudah lebih diperjelas dengan menampilkan representasi aljabar dalam applet.

Kesulitan dalam mengidentifikasi properti grafik fungsi trigonometri, diperbaiki dengan mengeksplorasi applet GeoGebra seperti tampilan pada Gambar 6. Setiap applet yang diberikan berfungsi untuk melengkapi atau saling menguatkan kegunaannya dalam eksplorasi yang dilakukan siswa. Pemahaman yang utuh dan jelas dalam representasi fungsi secara grafis sangat penting bagi siswa sebagai wujud nyata abstraksi dalam pemikirannya. Dengan mampu mengenali properti grafik, diharapkan siswa mampu mengembangkannya ke ranah penalaran yang lebih tinggi pada studistudi kasus masalah kontekstual terkait gejalagejala alam dan lingkungan sosial yang dapat direpresentasikan dalam grafik trigonometri.

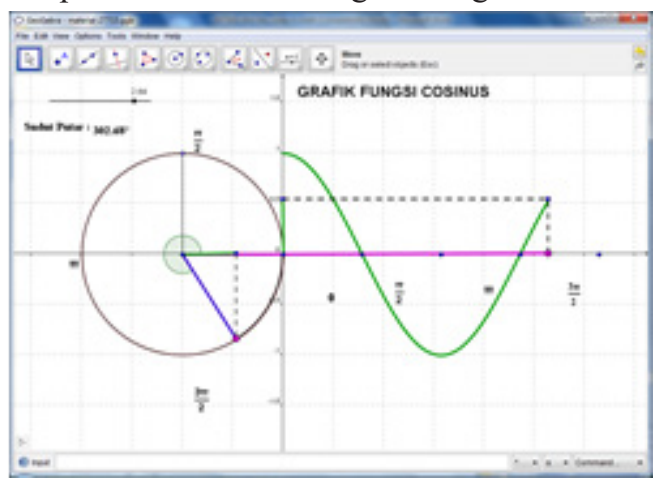

Gambar 6. Applet GeoGebra properti grafik fungsi trigonometri 
Hasil pengamatan menunjukkan bahwa pada proses eksplorasi siswa bereksplorasi kondisinya lebih kondusif, diskusi dengan kelompok lebih terarah. Pada sesi presentasi terjadi perdebatan hangat dengan topik yang lebih luas dibanding pada siklus I. Pada sesi kegiatan penutup, siswa dengan bimbingan guru mengadakan refleksi, penarikan simpulan (pelurusan kesalahan konsep) hasil diskusi dan penguatan konsep. Kegiatan eksplorasi di lakukan dalam 1 kali tatap muka, dan kegiatan presentasi dilakukan dalam 4 kali tatap muka. Kemudian pada tatap muka ke-6 diadakan tes siklus II yang terdiri dari 10 butir soal terkait konsep butir soal terkait konsep derajat dan radian, menentukan nilai fungsi trigonometri, mengidentifikasi properti grafik fungsi trigonometri, dengan hasil tersaji dalam Tabel 3 sebagai berikut.

Tabel 3. Deskripsi Hasil Tes Siklus II

\begin{tabular}{llccl}
\hline No. & Indikator & $\begin{array}{c}\text { Siklus } \\
\text { I }\end{array}$ & $\begin{array}{c}\text { Siklus } \\
\text { II }\end{array}$ & Keterangan \\
\hline 1 & $\begin{array}{l}\text { Nilai } \\
\text { terendah }\end{array}$ & 35 & 70 & Makin baik \\
\hline 2 & $\begin{array}{l}\text { Nilai } \\
\text { tertinggi }\end{array}$ & 90 & 100 & Makin baik \\
\hline 3 & Rata-rata & 67 & 89 & Makin baik \\
\hline 4 & Ketuntasan & $28 \%$ & $88 \%$ & Makin baik \\
\hline
\end{tabular}

Tabel 4. Deskripsi Rekap Hasil Tes

\begin{tabular}{llcccc}
\hline No & Indikator & $\begin{array}{c}\text { Tes } \\
\text { Awal }\end{array}$ & $\begin{array}{c}\text { Siklus } \\
\text { I }\end{array}$ & $\begin{array}{c}\text { Siklus } \\
\text { II }\end{array}$ & Keterangan \\
\hline 1 & $\begin{array}{l}\text { Nilai } \\
\text { terendah }\end{array}$ & 10 & 35 & 70 & Makin baik \\
\hline 2 & $\begin{array}{l}\text { Nilai } \\
\text { tertinggi }\end{array}$ & 55 & 90 & 100 & Makin baik \\
\hline 3 & Rata-rata & 21 & 67 & 89 & Makin baik \\
\hline 4 & $\begin{array}{l}\text { Ketun- } \\
\text { tasan }\end{array}$ & $0 \%$ & $28 \%$ & $88 \%$ & Makin baik \\
\hline
\end{tabular}

Terdapat peningkatan pencapaian nilai terendah, tertinggi, rata-rata kelas, dan banyaknya siswa yang tuntas atau mencapai Kriteria Ketuntasan Minimal $(\mathrm{KKM}=78)$. Pencapaian rata-rata kelas telah melampaui KKM (78), namun masih terdapat nilai terendah yang dicapai di bawah KKM yaitu 70. Berdasarkan hasil refleksi diketahui bahwa siswa dengan nilai 70 tersebut mengalami kesalahan prosedur karena tidak konsisten dan tidak hati-hati dalam mengerjakan soal. Di sisi lain ada $88 \%$ siswa yang mendapatkan skor tuntas. Peningkatan dari siklus I hingga siklus II dapat dilihat dalam Gambar 7 berikut ini.

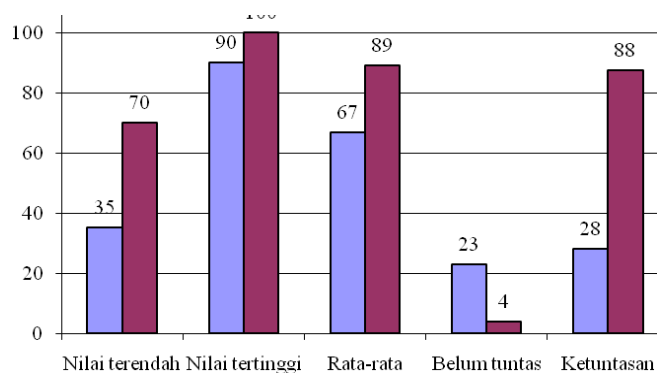

Gambar 7. Grafik Hasil Tes Siklus I dan II

Penelitian dengan dua siklus ini menerapkan strategi pembelajaran kooperatif yang menekankan pada eksplorasi konsep menggunakan applet GeoGebra dengan diskusi dan presentasi kelompok. Pada pembelajaran dengan strategi ini yang menjadi fokus pengamatan adalah proses pemahaman dan perbaikan kesalahan konsep, yang mengakibatkan peningkatan prestasi belajar. Rangkuman deskripsi hasil tes prestasi dari awal hingga siklus II ditunjukkan pada Tabel 4.

Berdasarkan data pada Tabel 4 tampak bahwa terdapat peningkatan pencapaian pada semua indiktor. Peningkatan dari tes awal, siklus I hingga siklus II dapat dilihat dalam Gambar 8 berikut ini.

\section{Gambar 8. Grafik Rekap Analisis Peningkatan Hasil Tes}

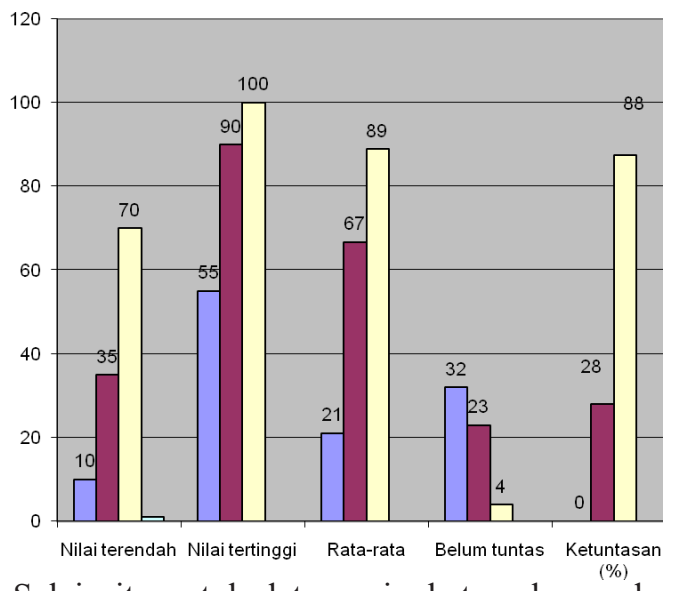

Selain itu untuk data peningkatan skor pada pemahaman konsep dapat dicermati pada Tabel 5 sebagai berikut. 
Tabel 5. Rekap Tipe Jawaban Tes Pemahaman Konsep Trigonometri

\begin{tabular}{lccc}
\hline \multicolumn{1}{c}{ Tipe Jawaban } & $\begin{array}{c}\text { Tes } \\
\text { Awal }\end{array}$ & Siklus I & $\begin{array}{c}\text { Siklus } \\
\text { II }\end{array}$ \\
\hline Jawaban benar & $15 \%$ & $64 \%$ & $86 \%$ \\
\hline Salah konsep & $22 \%$ & $8 \%$ & $2 \%$ \\
\hline $\begin{array}{l}\text { Salah prosedur atau } \\
\text { tidak merespons }\end{array}$ & $63 \%$ & $28 \%$ & $12 \%$ \\
\hline
\end{tabular}

Berdasarkan hasil Tabel 5 diketahui bahwa, rata-rata jumlah siswa yang menjawab benar meningkat dari $15 \%$, menjadi $64 \%$ pada siklus I, dan meningkat menjadi $86 \%$ pada siklus II. Rata-rata jumlah siswa yang mengalami salah konsep menurun dari $22 \%$, menjadi $8 \%$ pada siklus I, dan menurun lagi menjadi $2 \%$ pada siklus II. Sedangkan rata-rata jumlah siswa yang mengalami salah prosedur dan atau tidak merespons menurun dari $85 \%$, menjadi $36 \%$ pada siklus I, dan menurun lagi menjadi $14 \%$ pada siklus II.

Meskipun terdapat siswa yang masih mencapai nilai 70 (belum mencapai KKM 78), hal itu dikarenakan ketidaktelitiannya, bukan karena salah konsep. Temuan dalam siklus II, ada beberapa siswa yang mengalami salah konsep terhadap nilai pi. Siswa tidak berhasil menentukan nilai fungsi trigonometri dalam pi radian karena tidak terbiasa mengerjakan soal tipe ini, dan mengalami salah konsep tentang pi. Beberapa siswa mengalami kesalahan konsep dengan menganggap . Sehingga siswa bingung dan malas menentukan nilai fungsi trigonometri dengan ukuran sudut dalam pi radian. Hal ini menjadi masukan bagi pembelajaran berikutnya, bahwa untuk mempelajari fungsi trigonometri dan aplikasinya perlu terlebih dahulu diadakan apersepsi tentang penemuan dan pengetahuan tentang pi.

Secara keseluruhan untuk indikator pemahaman konsep dan hasil tes prestasi tersebut semuanya mencapai target yang diprogramkan. Hal ini menandakan bahwa penelitian ini berhasil sesuai dengan tujuan yang dicapai.

\section{Simpulan dan Saran}

Berdasarkan hasil Penelitian Tindakan Kelas (PTK) pada siswa kelas XI Mesin SMK N 2
Wonosari menggunakan model pembelajaran kooperatif dengan bantuan applet GeoGebra dapat ditarik kesimpulan: (1). Penggunaan model pembelajaran kooperatif dengan bantuan applet GeoGebra dapat meningkatkan prestasi siswa kelas XI Mesin SMK N 2 Wonosari dari peningkatan rata-rata kelas dari persentase banyaknya siswa menjawab soal pemahaman konsep dengan benar, sebelum tindakan sebesar $15 \%$ menjadi sebesar $64 \%$ pada siklus I, dan sebesar $86 \%$ pada siklus II. Selain itu dapat juga dilihat dari penurunan rata-rata kelas dari persentase banyaknya siswa yang menjawab soal pemahaman konsep dengan salah konsep, salah prosedur, dan atau tidak merespons, sebelum tindakan sebesar $63 \%$ menjadi sebesar $28 \%$ pada siklus I, dan sebesar $12 \%$ pada siklus II. (2). Penggunaan model pembelajaran kooperatif dengan bantuan applet GeoGebra dapat meningkatkan prestasi belajar siswa kelas XI Mesin SMK N 2 Wonosari dari nilai rata-rata kelas sebelum tindakan sebesar 21 dengan ketuntasan awal sebesar $0 \%$ menjadi nilai rata-rata kelas sebesar 67 dengan ketuntasan sebesar $28 \%$ pada siklus I, dan nilai rata-rata kelas sebesar 89 dengan ketuntasan sebesar $88 \%$ pada siklus II. Terlihat dari proses awal sampai siklus terakhir, kedua indikator kinerja dapat tercapai. Jadi kesimpulan dalam penelitian ini adalah pembelajaran trigonometri metode kooperatif dengan berbantuan applet GeoGebra tersebut dapat meningkatkan pemahaman konsep dan prestasi belajar siswa Kelas XI Mesin SMK N 2 Wonosari Kabupaten Gunungkidul Tahun Pelajaran 2014/2015.

Dengan memperbaiki kesalahan konsep yang terjadi pada siswa maka prestasi belajar siswa pada pembelajaran trigonometri dengan pembelajaran kooperatif berbantuan applet GeoGebra ini dapat meningkat, sehingga penelitian ini dapat dikatakan berhasil. Berdasarkan hasil tersebut disarankan: (1). Guru dalam pembelajaran matematika selalu berusaha mencari variasi strategi pembelajaran yang memberi kesempatan siswa untuk berdiskusi dan mengeksplorasi konsep menggunakan teknologi atau alat bantu kognitif lainnya, (2). Guru disarankan merespons kesulitan belajar siswa yang disebabkan 
oleh miskonsepsi pada konsep-konsep dasar materi terkait, (3). Siswa hendaknya dalam pembelajaran harus aktif, kreatif, dan inovatif dalam mengonstruksi pemahamannya sendiri agar dapat mengimplementasikan ilmu yang dipelajari dalam kehidupan sehari-hari, (4). Bagi penentu kebijakan hendaknya bersifat responsif, memberi fasilitas sarana, dan prasarana yang memadai untuk membantu kreativitas guru dan murid.

\section{Daftar Pustaka}

Blackett, N., \& Tall, D. (1991). Gender and the versatile learning of trigonometry using computer software. In F. Furinghetti (Ed.), Proceedings of the Fifteenth Conference of the International Group for the Psychology of Mathematics Education, Vol. 1, pp. 144-151.

Challenger, M. (2009). From triangles to a concept: a phenomenographic study of A-level students' development of the concept of trigonometry. Thesis. University of Warwick.

Demir, O. (2012). Students' concept development and understanding of sine and cosine functions. Thesis. Universiteit van Amsterdam.

Joolingen, W. V. (1999). Cognitive tools for discovery learning. International Journal of Artificial Intelligence in Education, 10, 385-397.

Kultur, M. N., Ozdemir, E., \& Konyalioglu, A.C. (2011). Identifying the Learning Difficulties of Freshmen in Mathematics Teacher Training Department in Function Graphs and Derivatives. International Journal of Humanities and Social Science Vol. 1 No. 7, 119-124.

Lotfi, F. H. \& Mafi, E. (2012). Efficacy of Computer Software on Trigonometry. Applied Mathematical Sciences, Vol. 6, 2012, no. 5, $229-236$.

Orhun, N. (2001). Students' mistakes and misconceptions on teaching of trigonometry. Proceedings of the International Conference New Ideas in Mathematics Education, Palm Cove:
Australia, 208-211.

Weber, K. (2005). Students' understanding of trigonometric functions. Mathematics Education Research Journal, 17(3), 91112.

Zengin, Y., Furkan, H., \& Kutluca, T. (2012). The effect of dynamic software geogebra on student achievement in teaching of trigonometry. Procedia - Social and Behavioral Sciences, 31, 183-187. 